\title{
Assessing the Productivity of Countries in the Asia Pacific
}

Nur Syiqim Mohd Syafiq Felix, Muhammad Asraf Abdullah, Jerome Kueh Swee Hui

To Link this Article: http://dx.doi.org/10.6007/IJARBSS/v10-i7/7413

DOI:10.6007/IJARBSS/v10-i7/7413

Received: 25 April 2020, Revised: 27 May 2020, Accepted: 12 June 2020

Published Online: 25 July 2020

In-Text Citation: (Felix et al., 2020)

To Cite this Article: Felix, N. S. M. S., Abdullah, M. A., \& Hui, J. K. S. (2020). Assessing the Productivity of Countries in the Asia Pacific. International Journal of Academic Research in Business and Social Sciences, 10(7), 245-264.

\section{Copyright: (C) 2020 The Author(s)}

Published by Human Resource Management Academic Research Society (www.hrmars.com)

This article is published under the Creative Commons Attribution (CC BY 4.0) license. Anyone may reproduce, distribute, translate and create derivative works of this article (for both commercial and non-commercial purposes), subject to full attribution to the original publication and authors. The full terms of this license may be seen at: http://creativecommons.org/licences/by/4.0/legalcode

\section{Vol. 10, No. 7, 2020, Pg. 245 - 264}

Full Terms \& Conditions of access and use can be found at http://hrmars.com/index.php/pages/detail/publication-ethics 


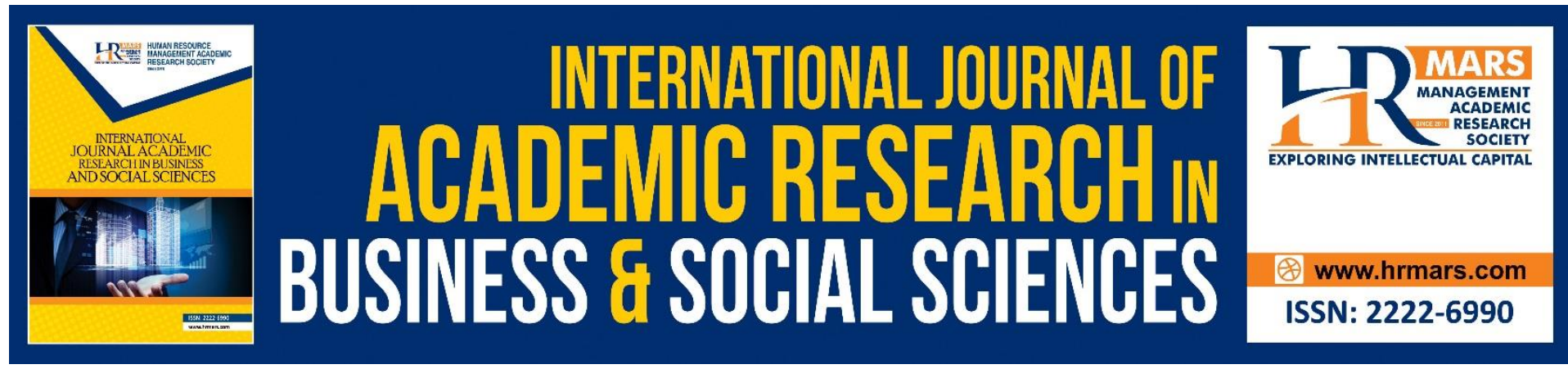

\title{
Assessing the Productivity of Countries in the Asia Pacific
}

\author{
Nur Syiqim Mohd Syafiq Felix, Muhammad Asraf Abdullah, \\ Jerome Kueh Swee Hui \\ Faculty of Economics and Business, Universiti Malaysia Sarawak, 94300 Sarawak, Malaysia. \\ Email: syiqimsyafiq@gmail.com, amasraf@unimas.my, kshjerome@unimas.my
}

\begin{abstract}
The main objective of this paper is to evaluate and discuss the productivity growth of postglobal financial crisis of 2008 for 16 countries in the Asia Pacific region. The productivity growth is measured by the total factor productivity (TFP) growth and is estimated using the Malmquist Productivity Index (MPI) technique based on the Data Envelopment Analysis (DEA) approach over the period of 2010-2017. The TFP indices of 16 countries were estimated using the DEAP 2.1 software. Overall, the Asia Pacific region shows the productivity growth of $-0.6 \%$ throughout a period from 2010 to 2016. The results convey that Asia Pacific region experienced the highest and positive growth of TFP in year 2013, 2010 followed by 2014. Meanwhile, year 2016 recorded negative and lowest TFP growth followed by year 2011, 2015 and 2012. The DEA-MPI result also revealed that the TFP growth for most of the countries in Asia Pacific region for the period of this study is driven by efficiency change rather than technological change due to low investment in innovative technology.
\end{abstract}

Keywords: Total Factor Productivity, Data Envelopment Analysis, Malmquist Productivity Index, Efficiency Change, Technological Change, Asia Pacific.

\section{Introduction}

Total Factor Productivity (TFP) is also known as multi-factor productivity or Solow residual which was initiated by Solow (1957). TFP is characterised as efficiency and intensity of utilisation of inputs in the production process. A higher TFP results in an improvement of technology, higher working capital and larger restoration of output. It increases the capacity of economy to generate a bigger output from a given inputs stock. Productivity growth is important as an indicator of a country's long-term prosperity (Krugman, 1991) and to expand competitiveness, job creation, economic growth and living standards (Douglas, 2017). Productivity growth is one of the important sources for economic growth besides factors of productions according to the neoclassical and endogenous growth theories.

Countries in the Asia Pacific region including more advanced countries such as Singapore and South Korea have been experiencing low productivity growth over the past 8 years since the eruption of the global financial crisis in 2008. In 2016, the TFP growth of Asia Pacific region was $-1 \%$ as compared to 2010 which is $0.5 \%$ of TFP growth (International Monetary Fund, 
2017). It is a clear indicator that economic recession has negatively affected the TFP growth in the Asia Pacific region. Using a sample dataset from China, Zhang and Liu (2017) contends that the reason for low TFP growth in China as compared to more developed countries especially since post 2008 crisis is due to low domestic and international demand which lead to higher debt leverage rate and reduction in fixed asset investment growth. An interesting question is how to address the declining trend of TFP growth during economic crisis?

This study is motivated by the low and downward trend of TFP growth in countries from the Asia Pacific region since the post global economic crisis in 2008. This paper contributes to the literature on total factor productivity of post-global financial crisis period, in order to identify the sources of productivity growth particularly in selected Asia Pacific region. Following the above productivity issue, this study is carried out under the hypothesis that the TFP growth in the Asia Pacific region is mainly driven by technical efficiency change (EFFCH) compared to technological change (TECHCH). This research is conducted with two objectives. Firstly, it is to estimate and compare productivity growth across sample countries, Secondly, it is to discuss the sources of productivity growth in Asia Pacific countries during the post-global financial crisis in 2008.

\section{Literature Review}

The framework for studying productivity has largely referred to the Solow (1956) and Swan (1956) neoclassical growth theories to design productivity model. The Solow-Swan aggregate production function describes growth of output, for example productivity as given in equation: $Y=K^{\alpha}(A L)^{1-\alpha}$ where $Y$ is the output growth or productivity growth, $K$ stands for stock capital, $L$ is total labour, $A$ refers to level of technology and $\alpha$ represents the elasticity of output with respect to capital. Thus, this model consists of three variables namely capital, labour and output. Technological innovation is also introduced in the model. However, the level of technology becomes the residual factor in elaborating the long-term productivity growth and was taken to be exogenous. Hence, the Solow-Swan neoclassical framework is occasionally called an exogenous growth model. The model assumes constant return to scale for one input and one output case, if both capital and labour increases at the same rate. However, there may be diminishing return to labour and capital if one input is held fixed while the other input is rising. The neoclassical growth model is advantageous in calculating productivity growth because the model implies a long run relationship between the inputs and the growth of productivity.

Studies on productivity using the Malmquist Productivity Index (MPI) technique was first introduced by Fare et al. (1994) to examine the productivity in 17 OECD countries over a period 1979 to 1988 . They decompose the TFP growth into three sources, namely, technical progress change, pure technical efficiency change and scale efficiency change. Findings deduced that the highest productivity growth was recorded by Japan which is almost half as compared to other samples due to the technical efficiency change. In another study, Rambaldi, Rao and Dolan (2007) computed the TFP growth for 69 countries for a period between 1982 to 2000 using the metafrontier DEA framework. The sample countries are grouped into four regions that are Asia Pacific, America, Europe and the Middle East respectively. The TFP is calculated using the MPI technique in which the capital stock and labour are used as the input variables and real GDP is the proxy for the output variable. 
Krishnasamy and Ahmed (2009) adopted the MPI based on Data Envelopment Analysis to measure and analyse the productivity growth performance of ASEAN-5 including Malaysia, Indonesia, Philippines, Thailand and Singapore using a dataset from 1993 to 2006. Findings show positive growth in TFP for Indonesia and Singapore, but negative growth for Malaysia, Philippine and Thailand. Meanwhile, Rath (2019) investigated the productivity convergence performance of ASEAN-5 using PS panel club convergence method. The result confirmed the presence of productivity convergence in South East Asian countries. Another research by Afzal and Manni (2013) focusing on TFP growth in ASEAN context showed that high TFP growth for Philippines and Singapore were contributed by both technical efficiency change and technological change. The study suggested that improvement in the efficiency of ICT sector and technological innovation could enhance the TFP growth in ASEAN region.

Then, Ahmed and Krishnasamy (2013) applied the meta-frontier framework to calculate the TFP growth of countries in three regions in Asia for the period of 1980 to 2006. Results show that Eastern Asia and ASEAN 5 experienced the highest TFP growth due to the improvement of technical efficiency change. However, countries in the three regions of Southern Asia, Eastern Asia and ASEAN 5 as a group recorded a negative rate of technological improvement. In a later year, Ahmed and Kialashki (2017) focused their study in the region of Asia Pacific countries in order to examine the determinants of TFP growth for a period from 1970 to 2012. Their study result suggests the spill over effect of foreign direct investment on technological progress in Asia Pacific. Both of these studies supported importance of sufficient infrastructures and labour capital to attract more foreign investments. Other work in this vein is found in Wayan (2013) who contended a negative productivity growth during Asian Financial Crisis in year 1997 due to negative technical efficiency change. Nonetheless, post crisis result reveals fast catching up in terms of productivity growth by China due to continuous improvement in technology development of the country.

This section presents selected literature that applies Malmquist Productivity Index based on DEA technique to estimate TFP growth of countries or regions. Nonetheless, to our knowledge there are few studies that investigate productivity growth of countries in the context of Asia Pacific region. The Asia Pacific region is selected as it is an emerging economic region that consists of fast growing economies namely China, India, South Korea, Australia and Japan.

\section{Methodology \\ Data Description}

This research applies the Malmquist Productivity Index based on Data Envelopment Analysis (MPI-DEA) to estimate the TFP of countries. The MPI technique is one of the most popular techniques used to estimate efficiency and productivity at both country and firm levels. For example, a study by Abdullah and Satar (2018) also applied the MPI based on DEA analysis in order to calculate the technical efficiency and productivity of airline companies.

The Asia Pacific countries are chosen as the sample for this study because the region contributes to the largest share of world's GDP at 46.81\% for 2019 (International Monetary Fund, 2019). A sample of 16 countries namely Australia, Bangladesh, Cambodia, China, India, Indonesia, Japan, Korea, Malaysia, Mongolia, Nepal, Pakistan, Philippines, Singapore, Sri Lanka and Thailand. The sample data are observed over a period of 2010 to 2017 . This sample period is selected in order to capture the trend of TFP during post global crisis of 2007 to 
2009. The original unit used for gross fixed capital formation and gross domestic products are measured in current prices using local currency of the respective countries. These data are converted into USD using the Purchasing Power Parities (PPP) of each country which follows Dam (2006) to account for inflation and exchange rate effect issue when conversion is done using ordinary exchange rate approach.

Table 01: Descriptive Statistics of DEA-MPI estimation (2010-2017)

\begin{tabular}{lllll}
\hline Variables & $\begin{array}{l}\text { Minimum } \\
\text { Value }\end{array}$ & $\begin{array}{l}\text { Maximum } \\
\text { Value }\end{array}$ & Mean & $\begin{array}{l}\text { Standard } \\
\text { Deviation }\end{array}$ \\
\hline $\begin{array}{l}\text { Total number of labours (In } \\
\text { millions) }\end{array}$ & 1.17 & 787 & 110 & 209 \\
\hline $\begin{array}{l}\text { Gross Fixed Capital } \\
\text { Formation (In billions USD) }\end{array}$ & 1.82 & 5,130 & 473 & 1,040 \\
\hline $\begin{array}{l}\text { Gross Domestic Products } \\
\text { (In billions USD) }\end{array}$ & 7.19 & 12,200 & 1390 & 2,540 \\
\hline
\end{tabular}

According to Table 1, the total number of labours for the sample of countries studied ranges from 1.17 million to 787 million with the mean of 110 million. The standard deviation of total labours recorded is 209 million. As for the gross domestic product has a minimum value of USD 7.19 billion and a maximum value of USD 12,200 billion with a mean of USD 1,390 billion. The standard deviation of the gross domestic product recorded is USD 2,540 billion. Meanwhile, the gross fixed capital formation ranges between USD 1.82 billion to USD 5,130 billion. The mean of gross fixed capital formation is 473 billion USD with the standard deviation of USD 1,040 billion.

The variables that are used as the inputs for the TFP estimation are proxied by real gross fixed capital formation (RGFCF) and total number of labour force. RGFCF is a proxy for capital stock while total labour force is employed to measure labour input used in producing the output which is RGDP. Even though the number of work hours is a better measure of labour, but for this study this measure is not employed due to incomplete data on total hour labours. This study uses total number of labours as applied in studies by Alvi and Ahmed (2014) and Sigit (2004).

Meanwhile, the output variable is proxied by real gross domestic product (RGDP) for the TFP growth estimation. These inputs and outputs are selected based on basic inputs and outputs commonly found in the Cobb-Douglas production function and have been used by past researchers in the study of TFP (Krishnasamy and Ahmed 2008); Arsana and Wu 2013; Islam, Salim and Bloch 2016; Olomola and Osinubi 2018; Zidouemba and Elitcha 2018). In terms of countries sample, this study meets the minimum requirement of the rule of thumb by employing two inputs and one output to estimate the TFP growth of 16 countries in Asia Pacific region. According to Golany and Roll (1989), as a rule of thumb for the DEA model to estimate efficiency and productivity of DMUs, the total number of DMU needs to be doubled with the total number of inputs and outputs. Meanwhile, Bowlin (1998) has stated that the minimum number of DMUs should be thrice the sum of inputs and outputs.

A further explanation of the input and output relationship for TFP estimation was discussed by Douglas (1948) who developed a simple production function to define input and output relationship. The measurement of TFP is based on the Cobb-Douglas functional form of 
production function which was widely used in economics to represent the relationship between an output and two inputs or more (Dholwal \& Reddy, 2016). The function that is used to model production was specified in the following form of the Solow-Swan model: $P(L, K)=B L^{\alpha} K^{\beta}$ where $P$ is the total production given by the monetary value of all goods produced in a year, $L$ is the labour input proxies by total employment, $K$ is the capital input that refers to the monetary worth of all machinery, equipment and buildings, $B$ is the TFP coefficient while $\alpha$ and $B$ are the output elasticities of labour and capital respectively.

The definitions and measurements of each inputs and output for TFP estimation is provided in Table 2.

Table 2 : TFP Estimation (DEA-Malmquist Productivity Index)

\begin{tabular}{lll}
\hline Subject & Variable & Definition \\
\hline Inputs: & $\begin{array}{l}\text { Employment } \\
\text { (Total } \\
\text { number of } \\
\text { labour force) }\end{array}$ & $\begin{array}{l}\text { Work force consists of people with age group of 15 } \\
\text { and older to supply manufacturing of goods and services } \\
\text { labour during a specific }\end{array}$ \\
\hline 2. & $\begin{array}{l}\text { Capital Stock } \\
\text { (RGFCF in } \\
\text { USD) }\end{array}$ & $\begin{array}{l}\text { Includes land improvements such as fences, ditches, } \\
\text { construction of roads, railways, schools, offices, hospitals, } \\
\text { private residential dwellings, commercial and industrial } \\
\text { buildings. Net recovery of valuables is also included in capital } \\
\text { formation. }\end{array}$ \\
\hline Output & RGDP in USD & $\begin{array}{l}\text { Sum of gross value added by overall resident } \\
\text { developed in the economy with any product taxes and } \\
\text { deducted by any subsidies not included in the products value. }\end{array}$ \\
\hline
\end{tabular}

Source: Geeta and Elsadig (2008)

\section{Estimation Technique}

This paper adopts a non-parametric DEA-MPI technique to gauge the TFP growth of the countries from the Asia Pacific region. The DEA technique utilizes a unique mathematical linear programming model to evaluate the efficiency and productivity of DMU introduced by Charnes, Cooper and Rhodes (1978). When outputs are comparatively larger to the input quantity, then the TFP has increased. The DEA allows the usage of panel data to approximate the occurrence in TFP growth.

The Malmquist Productivity Index is among the most acknowledged ways that is capable to trace change in productivity over a specific time period. Malmquist Index was initially built by Malmquist (1953). Then, Caves, Christensen and Diewert (1981) initially used the Malmquist Index to approximate TFP which is later known as the Malmquist Productivity Index (MPI). The main benefit of the Malmquist index is that it decomposes the TFP differences into TECHCH and EFFCH. The approximation of DEA-MPI is based on either input or output oriented distance functions. However, the aim of every country is to have maximal achievable output with the usage of restricted inputs resources. Furthermore, it is assumed that DMU is able to control the output. Thus, output directed based is used in this paper (Kruger, 2003). The output-oriented conceptualisation attempts to give the highest rise in output with a given number of inputs. 
In this paper, an output-oriented DEA model under the constant returns to scale (CRS) is used to estimate productivity change of countries in Asia Pacific. Tatje and Lovell (1995) demonstrated that the TFP index does not take into account the TFP change precisely under the variable return to scale (VRS) hypothesis where the Malmquist index normally results on biased reading under VRS technologies. Thus, distance functions should be measured according to the constant return to scale assumption. This paper reciprocates the findings of Fare et al. (1998) of which CRS assumption suits in approximating TFP growth using DEA-MPI.

The Malmquist index of TFP growth is estimated using the formula below where the two inputs which is $\mathrm{K}$ and $\mathrm{L}$ are derived by Shephard (1970) and Fare et al. (1988): $M_{h}^{t+1}\left(x_{h}^{t}, y_{h}^{t}, x_{h}^{t+1}, y_{h}^{t+1}\right)=\left[\frac{D_{h}^{t}\left(x_{h}^{t+1}, y_{h}^{t+1}\right)}{D_{h}^{t}\left(x_{h}^{t}, y_{h}^{t}\right)} \frac{D_{h}^{t+1}\left(x_{h}^{t+1}, y_{h}^{t+1}\right)}{D_{h}^{t+1}\left(x_{h}^{t}, y_{h}^{t}\right)}\right]^{\frac{1}{2}}$ where $h$ represents the country where $(h=1, \ldots, \mathrm{n}), t$ is the period of time, $D_{h}^{t}\left(x_{h}^{t+1}, y_{h}^{t+1}\right)$ is the distance function with respect to two different time periods, $x_{h}^{t}=\left(K_{h t}, L_{h t}\right)^{\prime}$ is input vector, $y_{h}^{t}=\left(y_{h t}\right)^{\prime}{ }^{1}$ is the economy wide output. Equation 3 shows a function which is defined as the reciprocal of the maximum proportional expansion of the output vector $y_{h}^{t}$, given inputs $x_{h}^{t}$. This equation depicts the output distance function to explain the productivity growth trends across period as the following equation: $D_{h}^{p}\left(x_{h}^{q}, y_{h}^{q}\right)=\left(\sup \left\{\varnothing:\left(x_{h}^{q}, \varnothing y_{h}^{q}\right) \in S(p)\right\}\right)^{-1} ; p, q=t, t+1$ where $p$ is the time period, $q$ is the time period, $h$ is the country and $S$ is the transformation of input into output.

The given Malmquist index is the geometric mean of two ratios of distance functions of the type which give the mutual of the maximum enhancement of the output in period $q$ (holding inputs constant) that is needed to reach a border point of the technology level in period $p: S(p)=\left\{\left(x_{h}^{p}, y_{h}^{p}\right): x_{h}^{p} \geq 0\right.$ can produce $\left.y_{h}^{p} \geq 0, \forall h=1, \ldots, n\right\}$. The Malmquist index denotes positive (negative) TFP growth between the periods $t$ and $t+1$ if it is larger (smaller) than 1.

The characteristics of the Malmquist index is that it can be decomposed into two factors which have a very informative economic interpretation (Fare et al., 1994) shown as

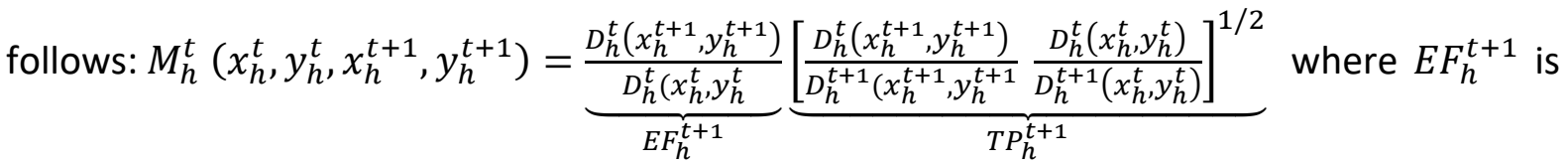
the technical efficiency change between periods $t$ and $t+1$ while $T P_{h}^{t+1}$ is the rate of technological change. Factors developments between periods $t$ and $t+1$ are expressed by values more than 1 and vice versa. In order to apply this mathematical theory to real data for inputs and output, a procedure for the measurement of the numerous distance functions is required. These calculations are analysed by solving the linear programming problems of DEA. The following equation illustrates the output-oriented envelopment form under the assumption of CRS for country, $h$ :

$$
\begin{gathered}
\max _{\emptyset, \lambda} \emptyset_{h} \\
\text { s.t. } \emptyset_{h} Y_{h q}-\sum_{i=1}^{n} \lambda_{i} Y_{i p} \leq 0 \\
\sum_{i=1}^{n} \lambda_{i} K_{i p} \leq K_{h q}
\end{gathered}
$$




$$
\begin{gathered}
\sum_{i=1}^{n} \lambda_{i} L_{i p} \leq L_{h q} \\
\lambda_{1, \ldots, \lambda_{n}} \geq 0
\end{gathered}
$$

Later, $D_{q}^{p}\left(x_{h}^{q}, y_{h}^{q}\right)=\emptyset_{h}^{-1}$ for all $(p, q) \in\{(t, t),(t, t+1),(t+1, t),(t+1, t+1)\}$ is set where $s$ is input, $h=$ time period, $q=$ time period, $\emptyset_{h}=$ maximisation, $n=$ share of output, $\lambda_{i} Y_{i p}=$ weighted linear of output, $\lambda_{i} K_{i p}=$ weighted linear of capital and $\lambda_{i} L_{i p}=$ weighted linear of labour.

Here, the combination of the input and output in period $q$ of each country is correlated with a linear frontier production function which adds the input-output merge of the highest productivity nations in period $p$. The maximisation increases $h$ as long as the first restraint is not disrupted and by that shows how much the output of country $h$ in period $q$ (holding capital and labour constant) can be rise in order to develop the frontier function that is constructed from the input-output combinations of all nation in period $p$. Thus, each country in period $q$ is related to a point on the frontier function that is constructed by a $\lambda$-weighted linear combination of the inputs and outputs of all countries in period $p$, where only those nations that are most correspondent to $h$ get selected a positive value of $\lambda$.

\section{Results and Discussions}

The TFP indices are obtained by running the DEA programming using a software called DEAP 2.1 developed by Coelli (1996). The TFP change value is decomposed into EFFCH and TECHCH. According to Mahadevan (2002), efficiency change gives the catching up effect in the production frontier while technological change is entailed shifting of production frontier. Results of the TFP growth for countries in Asia Pacific from 2010 to 2016 are reported in Table 3 and Figure 2. 
Table 3: $\quad$ TFP Growth in Asia Pacific Countries, 2010-2016

\begin{tabular}{|c|c|c|c|c|c|c|c|c|}
\hline $\begin{array}{l}\text { Year } \\
\text { Country }\end{array}$ & $\begin{array}{l}2010 \\
\text { TFP }\end{array}$ & 2011 & 2012 & 2013 & 2014 & 2015 & 2016 & $\begin{array}{l}\text { Geomean } \\
2010-2016\end{array}$ \\
\hline Australia & 1.150 & 1.044 & 0.997 & 0.965 & 0.955 & 0.947 & 1.064 & 1.015 \\
\hline Bangladesh & 1.002 & 0.987 & 1.033 & 1.041 & 1.029 & 1.016 & 1.008 & 1.016 \\
\hline Cambodia & 1.014 & 0.920 & 0.916 & 0.900 & 0.982 & 0.988 & 0.989 & 0.958 \\
\hline China & 1.017 & 1.001 & 1.002 & 1.016 & 1.031 & 1.022 & 1.026 & 1.016 \\
\hline India & 0.995 & 1.020 & 1.053 & 1.051 & 1.045 & 1.014 & 1.029 & 1.029 \\
\hline Indonesia & 1.009 & 0.964 & 1.018 & 0.980 & 0.985 & 1.017 & 1.024 & 0.999 \\
\hline Japan & 1.013 & 0.985 & 0.938 & 0.969 & 0.996 & 1.021 & 0.885 & 0.971 \\
\hline Korea & 1.010 & 1.022 & 1.012 & 1.005 & 0.994 & 0.988 & 0.957 & 0.998 \\
\hline Malaysia & 1.017 & 0.882 & 0.959 & 1.019 & 0.983 & 1.012 & 1.019 & 0.983 \\
\hline Mongolia & 0.756 & 1.080 & 1.137 & 1.320 & 1.316 & 0.988 & 0.889 & 1.051 \\
\hline Nepal & 1.037 & 1.031 & 0.919 & 0.961 & 0.841 & 0.971 & 0.852 & 0.942 \\
\hline Pakistan & 1.141 & 0.949 & 1.009 & 1.027 & 0.957 & 1.002 & 0.990 & 1.009 \\
\hline Philippines & 1.093 & 0.988 & 0.974 & 1.002 & 0.957 & 0.920 & 0.982 & 0.987 \\
\hline Singapore & 1.083 & 0.979 & 0.980 & 0.985 & 1.006 & 1.024 & 1.045 & 1.014 \\
\hline Sri Lanka & 0.933 & 0.924 & 0.997 & 1.058 & 1.069 & 0.969 & 1.018 & 0.994 \\
\hline Thailand & 0.943 & 0.970 & 1.064 & 1.022 & 1.004 & 1.022 & 0.604 & 0.933 \\
\hline $\begin{array}{l}\text { Geometric } \\
\text { mean }\end{array}$ & 1.009 & 0.983 & 0.999 & 1.017 & 1.005 & 0.995 & 0.954 & 0.994 \\
\hline
\end{tabular}

The overall geomean of TFP change for the Asia Pacific region between 2010 to 2016 shows a negative growth of $0.6 \%$. According to Asian Productivity Organisation (2016), the reason of this situation occur is because there are a huge amount of business closures and rising of unemployment rate during the crisis. During the past period of crisis, the increasing cost of labour has caused a reduction in production cost advantages in this region. As a result, many foreign companies have relocated the production base to advanced countries where production cost is cheaper. Besides that, despite the trade agreement made in trying to reduce the tariff barriers, most countries have increased the non-tariff barriers in combatting the effect of global crisis.

Among all of the countries in Asia Pacific, Mongolia held the highest positive geomean of TFP change for the period observed between 2010 to 2016 which is $5.1 \%$. These results are paralleled with the finding from Otgonsaikhan (2015) which suggests Mongolia's natural resources was the main contributor to the productivity and economic growth of the country. During this period, Mongolia has fully utilised its natural resources. For example, the share of exports of natural resources including coal, copper concentrate, iron, crude oil, zinc and gold has reached $99.2 \%$ in year 2013 which was exported to 60 countries. On the other hand, Thailand recorded the lowest TFP change which is $-6.7 \%$ across the period studied. This result is consistent with OECD (2013) which claimed that Thailand is lacking behind in terms of technology as well as research and development. In addition, the rice production and exportation which resembles one of the major economic activities of Thailand have low production of low yield of higher quality of rice. 
The best performance of TFP growth for Asia Pacific was recorded in year 2013 with the average TFP held positive growth of $1.7 \%$. During this year, Mongolia contributed the highest TFP growth in which it rose by $32 \%$ while Nepal has the lowest TFP growth which is $-3.9 \%$. This positive growth was contributed by 10 countries out of 16 countries including Bangladesh, China, India, Korea, Malaysia, Mongolia, Pakistan, Philippines, Sri Lanka and Thailand. This result is supported by Asian Productivity Organisation (2014) which stated that although the European Union countries were still facing the effect of European Debt Crisis, Asia Pacific's TFP growth has grown during this year. The positive change of TFP was due to tariff removal.

The second highest TFP growth for the region occurred in year 2010 with the growth of $0.9 \%$. According to Asia Productivity Organisation (2011), the Asia Pacific experience the fastest growing region in $\mathbf{2 0 1 0}$ due to favourable financial condition. During this time, Australia has achieved the highest value of TFP growth of $15 \%$. Meanwhile, the positive contributors of TFP growth was with the exception of only four countries which are India, Mongolia, Sri Lanka and Thailand with Mongolia recorded the lowest value of TFP growth of $-24.4 \%$. This is particularly true as according to UNESCAP (2011), these countries had witnessed high inflation rate and high level of debts. Due to this fact, the government has taken an action to hold the approved budget for public infrastructures. This condition constraint the TFP growth from occurring.

The third highest TFP growth for the region was $0.5 \%$ in 2014 which also marks as the last time whereby positive TFP growth ever occurred in this region during the period of this study. The contributors towards this growth achievement are Bangladesh, China, India, Mongolia, Singapore, Sri Lanka and Thailand. For example, China has induced the domestic demand through investing more in infrastructure investment in 2014 which are able to enhance the TFP growth (International Monetary Fund, 2014). The highest contributor to this growth in this particular year is Mongolia with a TFP growth of $31.6 \%$ from the effect of utilisation of natural resources while Cambodia reported the lowest TFP growth of $-10 \%$. This is reasonable since there is a drastic change in climate change and less competitiveness in terms of domestic and international markets which reduce the performance of the agricultural sector of the country (OECD, 2018).

The highest contributor to the negative growth of TFP in 2016 was Thailand which is $-39.6 \%$. According to Nidhiprabha (2017), Thailand is an export-driven economy. However, the Bank of Thailand (2017) has pointed out that in year 2016, Thailand export sector was hindered by China's new trade structure. China which was previously the main importer of Thailand's goods has reduced their imports as they have created a cheaper and sophisticated production process for petrochemical, chemical and electronic products. For instance, more high-end of smart phones has reduce the demand of Thailand's exports of hard disk drives. Besides that, the Thailand's foreign direct investment has reduced by 70\% compared to year 2015 as the local investors has bought over the retail businesses from foreign investors.

The second highest negative growth was recorded in 2011 with a negative growth of $1.7 \%$. Malaysia exhibits the highest contribution to the negative TFP growth of $-11.8 \%$ during this year. Some other countries which have negative TFP growth during this year were Bangladesh, Cambodia, Indonesia, Japan, Pakistan, Philippines, Singapore, Sri Lanka and Thailand. According to UNESCAP (2011), in 2011, the second stage of crisis that hit the United 
State has caused the oil and food price to increase. Besides that, the foreign capital inflows of this region also declined. As the effect, many countries have been facing with the inflation issue. The situation worsens when floods hit Cambodia, Thailand, Vietnam and South East Asia. Meanwhile Philippines has suffered from typhoons. These catastrophes have caused negative supply shocks to the productions of these countries.

The third highest negative growth of $-0.5 \%$ occurred in year 2015 . Countries that play the largest roles in contributing to this negative growth are Australia, Cambodia, Korea, Mongolia, Nepal, Philippines and Sri Lanka. During this year, Singapore has the highest TFP growth of $2.4 \%$ while Philippines encounter the lowest growth of TFP which is $-8 \%$. Singapore Tourism Board (2015) has asserted that the TFP growth of Singapore in 2015 was contributed by the rapid accumulation of capital and labour quality. On the other hand, the negative TFP growth of Philippines possibly due to the low quality of education in the country. Macha, Mackie and Magaziner (2018) have supported this result in which the Philippine's government has only invested $2.7 \%$ of the GDP for education. Besides that, the course of Mathematics, Science and Engineering in the tertiary level is not popular which lead to low innovation and TFP growth of the country.

The fourth lowest negative TFP growth of only $-0.1 \%$ was recorded in year 2012 . Half of the countries in this region possessed negative TFP growth during this year were Australia, Cambodia, Japan, Malaysia, Nepal, Philippines, Singapore and Sri Lanka. These unfavourable productivity growths are due to adverse effect of the European Debt Crisis, 2012 on many Asia Pacific countries. Additionally, major trading partners of Asia Pacific countries such as the United States and European Union are severely affected by the crisis which subsequently channel the negative impact on countries in Asia Pacific region (Asian Development Bank, 2012). Based on Table 3, Mongolia has the highest TFP growth of $13.7 \%$ while Japan experienced a regressive TFP growth of $6.2 \%$ which is the highest contributor to the overall negative TFP growth for the particular year. According to European Central Bank (2013), Japan was badly affected by the crisis due massive fiscal imbalance where the public debt rises from $67 \%$ of GDP in 1990 to $240 \%$ in 2012 during the crisis.

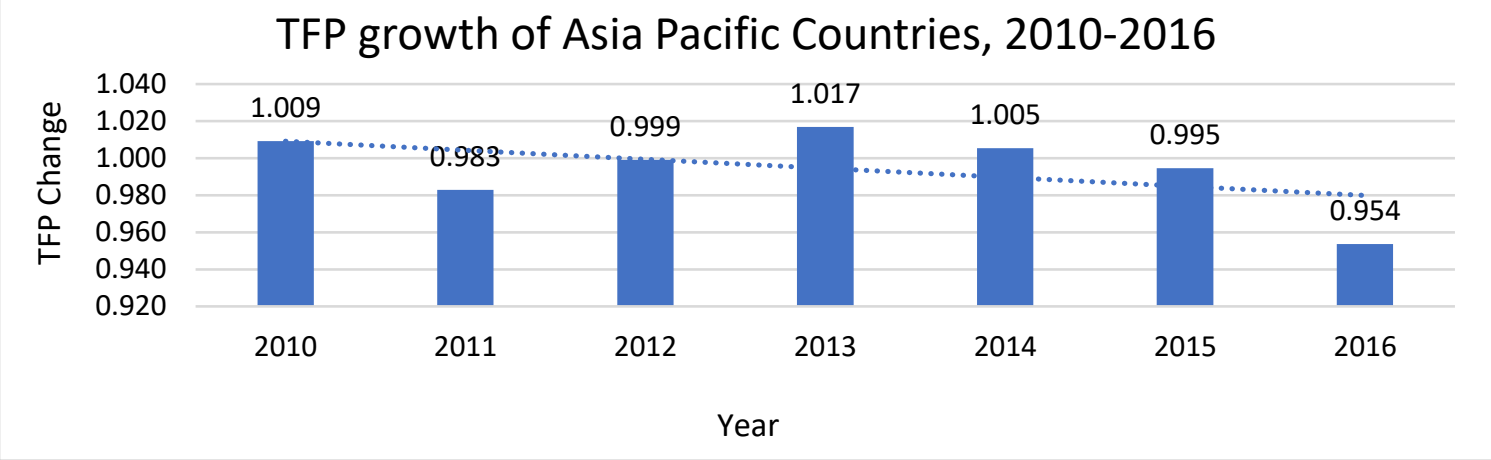

Figure 1: The Average of TFP Growth in Asia Pacific by Countries, 2010-2016

Figure 1 reveals that the average TFP growth in this region as a group has been affected in year 2011, 2014-2015 and 2016 where the TFP growth performance has declined. In general, this result suggests that the average TFP growth in Asia Pacific region are low and there was a decrement in TFP change. For instance, the TFP performance has declined by $-2.58 \%$ in 2011 as compared to 2010. According to Chakravarty and Cherian (2012), the European debt crisis 
which was erupted in 2011 has negatively affected the Asia Pacific economy. One of the biggest threats of the European debt crisis was on India's economy where the country has experienced a huge fall of $40 \%$ in its currency since year 2007 (Amadeo, 2019).

The only period in which the TFP growth had an increasing trend was from year 2012 to 2013. This was mainly due to the rise of private investment on gross fixed capital formation. The increase in the investment was led by the domestic and international investors in the manufacturing, mining and services sector. The growing behaviour of the TFP change as shown in Figure 1 lasted only a year. In 2014, again the TFP performance weakened by $-1.18 \%$ compared to 2013. This might be due to the Russian financial crisis. During the second half of 2014 , the price of crude oil was reduced by almost $50 \%$. This is due to decrement of global demand and increase production by the United States. Besides that, sanctions have affected access to capital and consequently slowing down the economic growth (Tracey, 2018).

Later in year 2015, the TFP change has reduced by $-1 \%$ as compared to year 2014 while in 2016, a sharp decline has occurred from year 2015 with a rate of $-4.12 \%$ compared to 2015 . During this time, China faced stock market turbulence. The Chinese stock market was continually falling although the government has ordered major stockholders to keep their share for the next six months (Qing and Takada, 2015). Following this incidence of this world's second-largest economy, the currencies of majority of Asia Pacific economies have dropped. Substantially, this is because those stockholders sell off their highly risked assets. Besides that, the Chinese currency market also faced devaluation during this time which rattle investors around the world and causes the world stock market to suffer (Allen, 2015). 
Table 4 and Figure 2 depicts the score of the TFP change and its decomposition which are the $\mathrm{EFFCH}$ and TECHCH.

Table 4: Summary of TFP, Efficiency Change and Technological Change of Asia Pacific Countries, 2010/2011-2016/2017

\begin{tabular}{|c|c|c|c|c|c|c|c|c|c|}
\hline $\begin{array}{l}\text { Countri } \\
\text { es }\end{array}$ & Score & $\begin{array}{l}2010 / 2 \\
011\end{array}$ & $\begin{array}{l}2011 / 2 \\
012\end{array}$ & $\begin{array}{l}2012 / 2 \\
013\end{array}$ & $\begin{array}{l}2013 / 2 \\
014\end{array}$ & $\begin{array}{l}2014 / 2 \\
015\end{array}$ & $\begin{array}{l}2015 / 2 \\
016\end{array}$ & $\begin{array}{l}2016 / 2 \\
017\end{array}$ & $\begin{array}{l}\text { Geome } \\
\text { an, } \\
2010- \\
2016\end{array}$ \\
\hline Australi & EFFC & & & & & & & & \\
\hline \multirow[t]{4}{*}{$a$} & $\mathrm{H}$ & 1.000 & 1.000 & 1.000 & 1.000 & 1.000 & 1.000 & 1.000 & 1.000 \\
\hline & $\mathrm{TECH}$ & & & & & & & & \\
\hline & $\mathrm{CH}$ & 1.150 & 1.044 & 0.997 & 0.965 & 0.955 & 0.947 & 1.064 & 1.015 \\
\hline & TFP & 1.150 & 1.044 & 0.997 & 0.965 & 0.955 & 0.947 & 1.064 & 1.015 \\
\hline & EFFC & & & & & & & & \\
\hline \multirow{3}{*}{ esh } & $\begin{array}{l}\mathrm{H} \\
\mathrm{TECH}\end{array}$ & 0.893 & 1.017 & 1.033 & 1.024 & 1.035 & 1.010 & 1.006 & 1.001 \\
\hline & $\mathrm{CH}$ & 1.122 & 0.971 & 1.000 & 1.016 & 0.994 & 1.005 & 1.002 & 1.015 \\
\hline & TFP & 1.002 & 0.987 & 1.033 & 1.041 & 1.029 & 1.016 & 1.008 & 1.016 \\
\hline \multirow[t]{4}{*}{$\begin{array}{l}\text { Cambo } \\
\text { dia }\end{array}$} & $\begin{array}{l}\text { EFFC } \\
\mathrm{H} \\
\mathrm{TECH}\end{array}$ & 0.894 & 0.990 & 0.908 & 0.879 & 1.062 & 0.987 & 1.018 & 0.960 \\
\hline & $\mathrm{CH}$ & 1.134 & 0.929 & 1.009 & 1.025 & 0.924 & 1.001 & 0.972 & 0.997 \\
\hline & TFP & 1.014 & 0.920 & 0.916 & 0.900 & 0.982 & 0.988 & 0.989 & 0.958 \\
\hline & EFFC & & & & & & & & \\
\hline \multirow[t]{4}{*}{ China } & $\begin{array}{l}\mathrm{H} \\
\mathrm{TECH}\end{array}$ & 1.019 & 1.025 & 1.040 & 1.038 & 1.027 & 1.011 & 1.036 & 1.028 \\
\hline & $\mathrm{CH}$ & 0.998 & 0.977 & 0.964 & 0.978 & 1.004 & 1.011 & 0.990 & 0.989 \\
\hline & TFP & 1.017 & 1.001 & 1.002 & 1.016 & 1.031 & 1.022 & 1.026 & 1.016 \\
\hline & EFFC & & & & & & & & \\
\hline \multirow[t]{3}{*}{ India } & $\begin{array}{l}\mathrm{H} \\
\mathrm{TECH}\end{array}$ & 0.948 & 1.047 & 1.070 & 1.048 & 1.048 & 1.007 & 1.029 & 1.027 \\
\hline & $\mathrm{CH}$ & 1.050 & 0.974 & 0.984 & 1.002 & 0.997 & 1.007 & 1.000 & 1.002 \\
\hline & TFP & 0.995 & 1.020 & 1.053 & 1.051 & 1.045 & 1.014 & 1.029 & 1.029 \\
\hline \multirow[t]{4}{*}{ ia } & $\begin{array}{l}\text { EFFC } \\
\mathrm{H} \\
\mathrm{TECH}\end{array}$ & 0.990 & 0.988 & 1.048 & 0.991 & 0.984 & 1.008 & 1.029 & 1.005 \\
\hline & $\mathrm{CH}$ & 1.019 & 0.975 & 0.972 & 0.989 & 1.000 & 1.009 & 0.995 & 0.994 \\
\hline & TFP & 1.009 & 0.964 & 1.018 & 0.980 & 0.985 & 1.017 & 1.024 & 0.999 \\
\hline & EFFC & & & & & & & & \\
\hline \multirow[t]{4}{*}{ Japan } & $\begin{array}{l}\mathrm{H} \\
\mathrm{TECH}\end{array}$ & 1.000 & 1.000 & 1.000 & 1.000 & 1.000 & 1.000 & 0.884 & 0.983 \\
\hline & $\mathrm{CH}$ & 1.013 & 0.985 & 0.938 & 0.969 & 0.996 & 1.021 & 1.001 & 0.989 \\
\hline & TFP & 1.013 & 0.985 & 0.938 & 0.969 & 0.996 & 1.021 & 0.885 & 0.971 \\
\hline & EFFC & & & & & & & & \\
\hline \multirow[t]{3}{*}{ Korea } & $\begin{array}{l}\mathrm{H} \\
\mathrm{TECH}\end{array}$ & 1.033 & 1.046 & 1.055 & 1.033 & 0.989 & 0.976 & 0.968 & 1.014 \\
\hline & $\mathrm{CH}$ & 0.978 & 0.977 & 0.959 & 0.973 & 1.005 & 1.012 & 0.988 & 0.984 \\
\hline & TFP & 1.010 & 1.022 & 1.012 & 1.005 & 0.994 & 0.988 & 0.957 & 0.998 \\
\hline
\end{tabular}


INTERNATIONAL JOURNAL OF ACADEMIC RESEARCH IN BUSINESS AND SOCIAL SCIENCES Vol. 10, No. 7, June, 2020, E-ISSN: 2222-6990 @ 2020 HRMARS

Table 4 continued

\begin{tabular}{|c|c|c|c|c|c|c|c|c|c|}
\hline Countries & Score & $\begin{array}{l}2010 / 201 \\
1 \\
\end{array}$ & $\begin{array}{l}2011 / 201 \\
2\end{array}$ & $\begin{array}{l}2012 / 201 \\
3\end{array}$ & $\begin{array}{l}2013 / 201 \\
4 \\
\end{array}$ & $\begin{array}{l}2014 / 201 \\
5\end{array}$ & $\begin{array}{l}2015 / 201 \\
6 \\
\end{array}$ & $\begin{array}{l}2016 / 201 \\
7\end{array}$ & $\begin{array}{l}\text { Geomean, } \\
\text { 2010-2016 }\end{array}$ \\
\hline \multirow[t]{3}{*}{ Malaysia } & $\begin{array}{l}\text { EFFCH } \\
\text { TECHC }\end{array}$ & 1.025 & 0.903 & 0.996 & 1.042 & 0.980 & 1.002 & 1.029 & 0.996 \\
\hline & $\mathrm{H}$ & 0.992 & 0.977 & 0.963 & 0.978 & 1.004 & 1.011 & 0.991 & 0.988 \\
\hline & TFP & 1.017 & 0.882 & 0.959 & 1.019 & 0.983 & 1.012 & 1.019 & 0.983 \\
\hline \multirow[t]{4}{*}{ Mongolia } & EFFCH & 0.750 & 1.106 & 1.177 & 1.341 & 1.316 & 0.980 & 0.892 & 1.060 \\
\hline & TECHC & & & & & & & & \\
\hline & $\mathrm{H}$ & 1.008 & 0.976 & 0.966 & 0.984 & 1.000 & 1.008 & 0.996 & 0.991 \\
\hline & TFP & 0.756 & 1.080 & 1.137 & 1.320 & 1.316 & 0.988 & 0.889 & 1.051 \\
\hline \multirow[t]{4}{*}{ Nepal } & EFFCH & 0.914 & 1.110 & 0.911 & 0.938 & 0.910 & 0.970 & 0.877 & 0.945 \\
\hline & TECHC & & & & & & & & \\
\hline & $\mathrm{H}$ & 1.134 & 0.929 & 1.009 & 1.025 & 0.924 & 1.001 & 0.972 & 0.997 \\
\hline & TFP & 1.037 & 1.031 & 0.919 & 0.961 & 0.841 & 0.971 & 0.852 & 0.942 \\
\hline \multirow[t]{4}{*}{ Pakistan } & EFFCH & 1.000 & 1.000 & 1.000 & 1.000 & 1.000 & 1.000 & 1.000 & 1.000 \\
\hline & TECHC & & & & & & & & \\
\hline & $\mathrm{H}$ & 1.141 & 0.949 & 1.009 & 1.027 & 0.957 & 1.002 & 0.990 & 1.009 \\
\hline & TFP & 1.141 & 0.949 & 1.009 & 1.027 & 0.957 & 1.002 & 0.990 & 1.009 \\
\hline \multicolumn{10}{|l|}{ Philippine } \\
\hline \multirow[t]{4}{*}{$\mathrm{s}$} & EFFCH & 1.030 & 1.015 & 0.991 & 1.002 & 0.960 & 0.913 & 0.985 & 0.984 \\
\hline & TECHC & 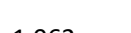 & 7 & (200 & P०००० & م000 & 1000 & דתחת & 1007 \\
\hline & $\mathrm{H}$ & 1.062 & 0.973 & 0.983 & 0.999 & 0.998 & 1.008 & 0.991 & 1.003 \\
\hline & TFP & 1.093 & 0.988 & 0.974 & 1.002 & 0.957 & 0.920 & 0.982 & 0.987 \\
\hline \multirow[t]{4}{*}{ Singapore } & EFFCH & 1.007 & 0.984 & 1.030 & 0.983 & 1.002 & 1.074 & 0.970 & 1.007 \\
\hline & TECHC & & & & & & & & \\
\hline & $\mathrm{H}$ & 1.075 & 0.995 & 0.951 & 1.002 & 1.005 & 0.953 & 1.077 & 1.007 \\
\hline & TFP & 1.083 & 0.979 & 0.980 & 0.985 & 1.006 & 1.024 & 1.045 & 1.014 \\
\hline \multirow[t]{4}{*}{ Sri Lanka } & EFFCH & 0.909 & 0.947 & 1.026 & 1.072 & 1.068 & 0.960 & 1.024 & 0.999 \\
\hline & TECHC & & & & & & & & \\
\hline & $\mathrm{H}$ & 1.027 & 0.975 & 0.971 & 0.987 & 1.001 & 1.009 & 0.994 & 0.995 \\
\hline & TFP & 0.933 & 0.924 & 0.997 & 1.058 & 1.069 & 0.969 & 1.018 & 0.994 \\
\hline \multirow[t]{4}{*}{ Thailand } & EFFCH & 0.927 & 0.994 & 1.097 & 1.035 & 1.003 & 1.012 & 0.608 & 0.939 \\
\hline & TECHC & & & & & & & & \\
\hline & $\mathrm{H}$ & 1.017 & 0.976 & 0.970 & 0.987 & 1.001 & 1.009 & 0.993 & 0.993 \\
\hline & TFP & 0.943 & 0.970 & 1.064 & 1.022 & 1.004 & 1.022 & 0.604 & 0.933 \\
\hline \multirow[t]{4}{*}{ Geomean } & EFFCH & 0.956 & 1.010 & 1.022 & 1.023 & 1.021 & 0.994 & 0.953 & 0.996 \\
\hline & TECHC & & & & & & & & \\
\hline & H & 1.056 & 0.974 & 0.978 & 0.994 & 0.985 & 1.001 & 1.001 & 0.998 \\
\hline & TFP & 1.009 & 0.983 & 0.999 & 1.017 & 1.005 & 0.995 & 0.954 & 0.994 \\
\hline
\end{tabular}




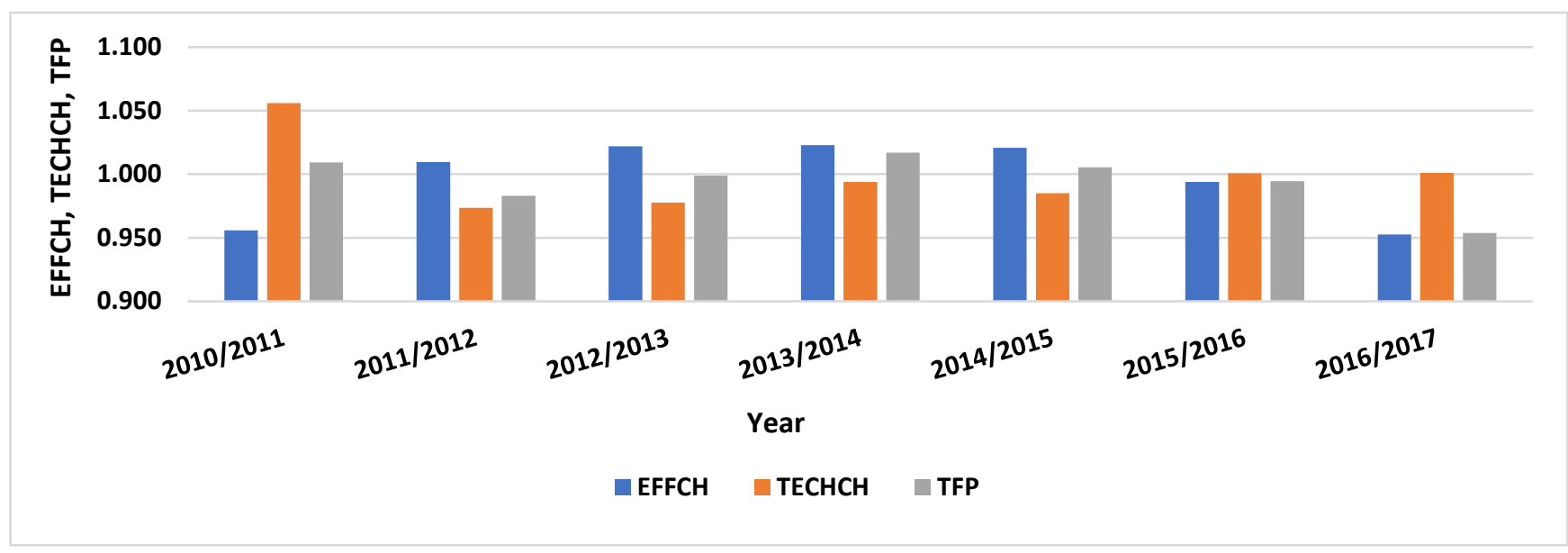

Figure 2: TFP, EFFCH and TECHCH of Asia Pacific Countries, 2010/2011-2016/2017

Table 4 and Figure 2 depict that in year 2010/2011, the increase in TECHCH has caused a positive TFP growth. The TFP growth is driven by the growth in TECHCH by $5.6 \%$. This shows that the Asia Pacific region was increasingly adopting innovations like electronics and technology in their productions. For example, Philippines has undergone technology upgrading through non-equity mode in which technology and knowledge are transferred internationally through franchising, service outsourcing and contract manufacturing in technological industry such as electronics, automotive components and pharmaceuticals (United Nations, 2011). However, there is a negative catching-up effect in this region. This is because the educational capabilities are not aligned with the technological change. For instance, there are still a lack of skills in handling complex information technology (IT) projects which rapidly increasing (Jura, 2010). This causes the EFFCH to decline in this particular year.

From the year $2011 / 2012$ to $2014 / 2015$, the TFP growth is driven by EFFCH. This result implies that the Asia Pacific region is an efficiency driven region during this period. This indicates that the industry uses the inputs of factors of production such as labour efficiently. In 2011/2012 and 2012/2013, although the EFFCH contribute the most to TFP growth, however the TFP growth was negative. This is because there were only small positive changes of EFFCH during those years which are $1 \%$ and $2.2 \%$ respectively. During this period, the global economic crisis has hit Asia Pacific labour market as well. For instance, the total labour of Indonesia and the Philippine has decreased by 333,000 and 882,000 respectively for the period between 2012 to 2013 (UNESCAP, 2013).

According to the Asian Productivity Organisation (2017), the Asia Pacific region could improve the TFP growth if the countries has balanced EFFCH and TECHCH. In order to stimulate TFP, the Asia Pacific countries needs to make a move in adopting technologies from developed countries. Moreover, EFFCH is also needed as less productive workers and insufficient capital pulls down the TFP growth especially for the developing economies. In addition, the region also experiences negative TECHCH during 2011/2012 and 2012/2013 period which were $-2.6 \%$ and $-2.2 \%$ respectively. These results are supported by United Nations (2013) which mentioned that FDI inflows in South Asia has decreased by $24 \%$ in 2012 . According to the Endogenous Growth Theory, FDI plays an important role in channelling the diffusion of technology from developed to developing countries in order to generate a better economic 
and productivity growth. On the other note, FDI inflows declined globally including Asia Pacific in all three types of economies which are developed, developing and transition economies. This is in line with the theories of neoclassical and endogenous growth which suggesting the role of the FDI in stimulating the TFP through technological change and sharing of ideas among countries (Grossman \& Helpman, 1995; Ibrahim, 2012).

During the 2013/2014 and the 2014/2015 period, the Asia Pacific region exhibits positive growth in TFP which are still dominated by EFFCH of $2.3 \%$ and $2.1 \%$ respectively. In 2013/2014, the countries that held positive EFFCH are Bangladesh, China, India, Korea, Malaysia, Mongolia, Philippines, Sri Lanka and Thailand. As stated by UNESCAP (2017), this might be due to the reason that Asia Pacific countries have made a structural reform by having holistic planning and effectiveness in public spending between year 2013 and 2014 as steps in recovering from the effect of European Debt Crisis.

Meanwhile, in 2014/2015, the countries that have positive EFFCH are Bangladesh, Cambodia, China, India, Mongolia, Singapore, Sri Lanka and Thailand. The Asian Development Bank (2015) has stated that between the period of 2014 to 2015, Asia Pacific countries have invested on human capital, education and training which eventually foster the skills of labours. However, this region has particularly focused on quantity instead of quality which would have not much effect on TFP. The TECHCH has also improved during 2013/2014 although the value is still negative which are from $-2.2 \%$ in $2012 / 2013$ to $-0.6 \%$ in $2013 / 2014$. According to UNESCAP (2016), technology has allowed the Asia Pacific region to catch up for better TFP growth. Nevertheless, there are still many countries such as Bangladesh, Cambodia, Indonesia, Nepal, Pakistan and Philippine that are not capable to adopt better technology and not able to keep the pace in competing with other countries. During this period, the improvement of $\mathrm{EFFCH}$ and $\mathrm{TECHCH}$ eventually lead to positive growth of TFP during these periods.

In year $2015 / 2016$, the TFP index was solely contributed by TECHCH of $0.1 \%$. Information and Communications Technology (ICT) is useful in disseminating knowledge sharing information and improve access to basic services. However, in year 2015, Asia Pacific was quite slow in terms of broadband uptake. The usage of fixed broadband penetration in this region is 11.2 subscriptions over 100 people which is below global average. This weak ICT connectivity is strongly related to e-commerce to reach global business. This might be the reason of low $\mathrm{TECHCH}$. Another reason of very low TECHCH in year 2015/2016 might be due to the declining of trade as a whole in Asia Pacific region. As reported by UNESCAP (2016), this region faced $9.7 \%$ and $15 \%$ of decrement in export and import in year 2015 due to falling price. According to Pietrucha and Zelazny (2019), countries of exporters tend to gain diverse knowledge and feedback from oversea buyers and trading partners that could improvise the competitive goods accordingly. The situation of low trade and export however reduces the knowledge flows into these countries and cause the TFP to decline in this particular year.

Due to the small increment of $0.1 \% \mathrm{TECHCH}$ and negative catching-up effect by $-0.6 \%$ of EFFCH, Asia Pacific region encounter negative TFP growth in 2015/2016. UNESCAP (2015) has reported the reason of negative EFFCH in year 2015 where Asia Pacific region undergo the highest total of natural disaster with an amount of $47 \%$ of world's disasters. South Asia alone has suffered $64 \%$ amount of world's death due to natural disasters such as earthquakes, 
floods, storms, droughts and cyclones. This situation definitely damages the buildings and equipment as well as loss of lives of human capital. Due to the limited financial resources, most of the developing countries struggle to pay for the recovery of the country.

A similar observation is shown in year 2016/2017 in which the TFP index experience negative growth which mainly driven by a negligible growth of $\mathrm{TECHCH}$ of $0.1 \%$. The countries that exhibit positive TECHCH are only Australia, Bangladesh, Japan and Singapore. This implies that these countries were leading in technology in this particular year. This is justified in the report of United Nations (2017) in which Australia, Singapore and Japan FDI inflow increased significantly. Besides that, FDI inflow in Bangladesh had also increase due to the announcement of huge electricity project in year 2016. During this period, the geomean of EFFCH deteriorated heavily with the geomean of $-4.7 \%$. This denotes that the Asia Pacific region still has a negative capability of catching-up effect to reach the optimal production frontier during 2016/2017.

Over the sample period of 2010/2011 to 2016/2017, Table 4 shows that Mongolia recorded the most successful country for catch-up with EFFCH geomean of $6 \%$ growth while Thailand held the lowest EFFCH of geomean with $-6.1 \%$ growth. This is generally true as Mongolia benefited from efficiency gains following its market reform of transition economies. ${ }^{1}$ According to Cheng (2003), efficiency gains appear to have been the main factor for pick-up growth in Mongolia ever since the transition to a market economy. A mass privatisation occurs in Mongolia after the economic transition. Due to this factor, most firms operate more efficiently due to competitiveness and profit purpose. Thus, a combination of economic reforms and privatisation enhance TFP. As for Thailand of the lowest EFFCH, this country depends heavily on export. Thailand export growth was negative from the period of 2013 to 2016 due to baht appreciation. This causes local product to be expensive for international buyers which lead to depreciation in demand for exports. Hence, in order to reduce cost, the employers need to cut jobs. This leads to a decline in EFFCH due to insufficient input of labours. As a result, the remaining labours have to work more than usual which will eventually lower the production output and efficiency as these labours experience fatigue and poor mental attitude due to unusual physical exertion as highlighted by Tran, Alauddin and Do (2019).

On the other hand, during the duration from year 2010/2011 to 2016/2017, Australia and Bangladesh are the best performing countries in terms of $\mathrm{TECHCH}$ with a $1.5 \%$ increment in innovation improvement. This is particularly true as both of these countries experience an increase in economic value in innovation between 2010 to 2016. According to the Department of Industry, Innovation and Science of Australia (2016), the Australian innovation active businesses perform better than non-innovation active businesses by four times higher for range of goods and services offered, three times higher for expenditure on IT and three times more training for employees. To no surprise, the World Economic Forum (2013) ranked Australia as the first country in Asia Pacific for high quality research institutions. On top of that, New South Wales Innovation and Productivity Council (2019) stated that Australia has a significant level of collaboration between universities and the industry since year 2010.

\footnotetext{
${ }^{1}$ An economy that is changing from being under government control to being market economy in which companies are not being controlled by the government.
} 
On the other hand, Bangladesh has also the similar value of geomean of TECHCH with Australia along the years of the study period. Bangladesh main economic activity is agriculture in which the country's employment in agriculture is 43\% in the year 2016 out of the percentage of total employment (World Bank, 2019). Schulenburg et al. (2017) has pointed out that Bangladesh has successfully tackle the impact of climate change on human and ecological system through the implementation of technology of capital goods and equipment.

In this study, it is indicated that most of the countries in the Asia Pacific regions from the period of 2010/2011 to 2016/2017 are led by EFFCH as compared to TECHCH for their productivity growth. This is in line with the United Nations (2011) which stated that the Asia Pacific region has been driven by accumulation of labour and capital in the production process in which the TFP is enhanced by increasing the output while using the same amount of capital and labour efficiently.

\section{Conclusion}

This study is carried out to investigate the recent declining trend of the TFP growth in countries from the Asia Pacific's region. This is parallel with the motivation of the study which is to discuss the issue of low and downward trend of TFP growth of the selected countries from the Asia Pacific region.

The results convey that countries from the Asia Pacific's region suffers a downward trend in the TFP growth. The only positive TFP growths recorded were for years 2010, 2013 and 2014 while for years 2011, 2012, 2015 and 2016, the region has witnessed a negative growth of TFP. The empirical findings from this study suggest that the TFP growth in the Asia Pacific region is contributed by both technical efficiency change and technological change. It is also shown from the finding that the main driver of TFP growth in the Asia Pacific region is technical efficiency change. These findings support the research hypothesis of this study. This is because, labour cost is relatively low in this region as compared to other industrialised countries in Europe and the United States (International Labour Organisation, 2014). Meanwhile, the rate of technological adoption in the production was led by Australia, Bangladesh, Pakistan, Singapore, the Philippine and India. In contrast, the rest of the countries in the study sample are lagging behind with a negative rate of technological adoption due to insufficient allocation of budget for innovation improvement.

As shown in the results from this study, there are two sources of TFP growth namely, technical efficiency change and technological change. These findings suggest that the catch-up ability (efficiency change) and innovation improvement (technological change) of countries from the Asia Pacific region were averagely low and unstable over the period of 2010 to 2017. Therefore, the government may promote and encourage firms to prepare the labours with new knowledge and skills to increase the capacity of labour's absorption of fast development in technology today. Furthermore, the government should allocate more funds for research and development activities in order to expand the capacity of a country's innovation. This is because innovation is the essence of TFP growth.

This study fills the research gap in existing literatures on TFP growth for countries from the Asia Pacific region for the period of post 2008 global financial crisis which are in line with the 
Neoclassical growth theory introduced by Solow (1956) and Swan (1956) and Endogenous growth theory which was introduced by Romer (1986). This paper is important in applying to the existing knowledge of the mentioned theories by identifying the sources of TFP growth for each country in the sample study in order to aid policy makers to efficiently promote countries' TFP growths in the future.

\section{Acknowledgement}

We would like to thank Malaysia's Ministry of Higher Education (MOHE) for funding this research under the Research Acculturation Grant Scheme, (RAGS/SS02(03)/1312/2015(06)).

\section{References}

Abdullah, M. A., \& Satar, N. M. (2018). The Impact of Outsourcing on Airlines' Performance: Empirical Evidence from Asia and Countries in the Pacific. Airline Economics in Asia (Advances in Airline Economics), Volume 7, 195-219. Emerald Publishing Limited. https://doi.org/10.1108/S2212-160920180000007011

Afzal, M. N. I., \& Manni, U. H. (2013). An empirical productivity analysis of ASEAN economies in transition towards knowledge-based economy. Asian Research Policy, 4(1), 1-9.

Ahmed, E. M., \& Kialashki, R. (2017). Asia Pacific productivity development determinants. World Journal of Entrepreneurship, Management and Sustainable Development.

Ahmed, E. M., \& Krishnasamy, G. (2013). Human capital investment to achieve knowledgebased economy in ASEAN5: DEA applications. Journal of the Knowledge Economy, 4(4), 331-342.

Alvi, S., \& Ahmed, A. M. (2014). Analyzing the impact of health and education on total factor productivity: A panel data approach. Indian Economic Review, 49(1), 109-123.

Färe, R. (1988). Fundamentals of production theory. Berlin, Germany: Springer-Verlag.

Färe, R., Grosskopf, S., \& Roos, P. (1998). Malmquist productivity indexes: a survey of theory and practice. In Index numbers: Essays in honour of Sten Malmquist (pp. 127-190). Dordrecht, Netherlands: Springer.

Grossman, G. M., \& Helpman, E. (1995). Trade wars and trade talks. Journal of Political Economy, 103(4), 675-708.

Ibrahim, A. (2012). The impact of foreign direct investment on total factor productivity and economic growth in Turkey. The Journal of Developing Areas, 46(1), 17-29.

Islam, A., Salim, R., \& Bloch, H. (2016). Does regional integration affect efficiency and productivity growth? Empirical evidence from South Asia. Review of Urban \& Regional Development Studies, 28(2), 107-122.

Rath, B. N. (2019). Does total factor productivity converge among ASEAN countries? Buletin Ekonomi Moneter dan Perbankan, 21, 477-494.

Krishnasamy, G., \& Ahmed, E. M. (2009). Productivity growth analysis in OECD countries: Application of metafrontier functions. The Journal of the Korean Economy, 10(2), 225244.

Krugman, P. (1991). Increasing returns and economic geography. Journal of Political Economy, 99(3), 483-499.

Nidhiprabha, B. (2017). The rise and fall of Thailand's export-oriented industries. Asian Economic Papers No.16/3. doi:10.1162 https://www.mitpressjournals.org/doi/pdf/10.1162/asep_a_00556. 
Olomola, P. A., \& Osinubi, T. T. (2018). Determinants of total factor productivity in Mexico, Indonesia, Nigeria, and Turkey (1980-2014). Emerging Economy Studies, 4(2), 192217. https://doi.org/10.1177\%2F2394901518795072

Pietrucha, J., \& Żelazny, R. (2019). TFP spillover effects via trade and FDI channels. Economic Research-Ekonomska Istraživanja, 32(1), 1-17. https://doi.org/10.1080/1331677X.2019.1629327.

Solow, R. (1956). A contribution to the theory of economic growth. Quarterly Journal of Economics, 70(1), 65-94.

Solow, R. M. (1957). Technical Change and the Aggregate Production Function. The Review of Economics and Statistics, 39(3), 312. doi:10.2307/1926047.

Swan, T. W. (1956). Economic growth and capital accumulation. Economic Record, 32(2), 334361.

Tatjé, E.G., \& Lovell, C. K. (1995). A note on the Malmquist productivity index. Economics Letters, 47(2), 169-175.

Zhang, D., \& Liu, D. (2017). Determinants of the capital structure of Chinese non-listed enterprises: Is TFP efficient? Economic Systems, 41(2), 179-202.

Zidouemba, P. R., \& Elitcha, K. (2018). Foreign Direct Investment and Total Factor Productivity: Is There Any Resource Curse. Modern Economy, 9(03), 463. 